Terbit online pada laman web jurnal : http://e-journal.sastra-unes.com/index.php/JIPS

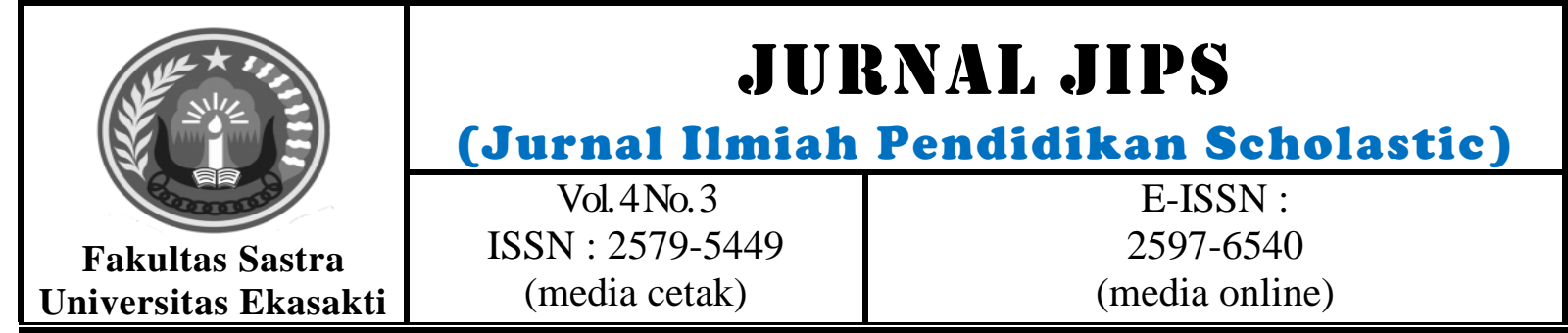

\title{
PENGEMBANGAN PERANGKAT PEMBELAJARAN MATEMATIKA BERBASIS PEMECAHAN MASALAH UNTUK PENINGKATAN BERPIKIR KREATIF PESERTA DIDIK KELAS X SMA KARTIKA 1-5 PADANG
}

\author{
Dina Novarina Perdana \\ Dosen FKIP, Universitas Ekasakti padang \\ dinanovarinaperdana@gmail.com
}

\begin{abstract}
Abstrak
Penelitian ini difokuskan pada permasalahan perangkat pembelajaran matematika yang belum mampu meningkatkan kemampuan berpikir kreatif peserta didik untuk menemukan pemahaman materi pelajaran matematika yang menyebabkan hasil belajar peserta didik rendah di kelas X SMA Kartika 1-5 Padang. Oleh karena itu, dikembangkan perangkat pembelajaran matematika berbasis pemecahan masalah utuk peningkatan kemampuan berpikir kreatif peserta didik berupa Rencana Pelaksanaan Pembelajaran (RPP) dan Lembar Kerja Peserta Didik (LKPD).Target khusus yang ingin dicapai dalam penelitian ini yaitu untuk dijadikan bahan ajar dan acuan bagi para pendidik di tingkat SMA, karena diharapkan guru mampu memainkan peran sebagai inovator pembelajaran. Seorang guru harus mampu menggunakan metode yang tepat sehingga dapat mengubah pandangan siswa yang keliru terhadap matematika, yang pada akhirnya matematika menjadi pelajaran yang mudah, menarik serta menyenangkan bagi semua peserta didik. Penelitian ini juga diharapkan sebagai contoh penelitian untuk mata kuliah metodologi penelitian di Fakultas Keguruan dan Ilmu Pendidikan (FKIP) Universitas Ekasakti.

Metode yang akan dicapai dalam pencapaian tujuan penelitian ini adalah dengan menggunakan model pengembangan yang dikemukakan Tesmer. Bahan ajar berbasis pemecahan masalah yang terdiri atas Rencana Pelaksanaan Pembelajaran (RPP) dan Lembar Kerja Peserta Didik (LKPD). Validasi bahan ajar dilakukan oleh ahli pendidikan matematika dan bahasa. Praktikalitas diselidiki melalui observasi pelaksanaan pembelajaran, pemberian angket kepada siswa dan wawancara dengan siswa serta dengan guru. Efektifitas diselidiki melalui observasi aktivitas dan tes hasil belajar siswa, analisis data dilakukan secara deskriptif. Luaran yang diharapkan dalam penelitian ini adalah menghasilkan LKPD yang valid, praktis dan efektif, dipublikasikan di jurnal nasional tidak terakreditasi dan menghasilkan prossiding seminar nasional.
\end{abstract}

Keywords: RPP, LKPD, Pemecahan Masalah, Berpikir Kreatif

(c) 2020 Jurnal JIPS

Jurnal JIPS (Jurnal Ilmiah Pendidikan Scholastic ) Vol. 4 No. 3 (2020) ISSN : 2579-5449

This work is licensed under a Creative Commons Attribution-NonCommercial 4.0 International License. 


\section{INTRODUCTION}

Berdasarkan hasil wawancara dengan 2 orang guru matematika dan observasi yang dilakukan di SMA Kartika 1-5 Padang, peneliti mendapati realitas yang terjadi di sekolah diantaranya masih cukup banyak peserta didik kurang memahami materi dalam pembelajaran matematika. Berdasarkan hasil pengamatan ini juga terlihat bahwa pembelajaran hanya terpusat pada guru sehingga selama proses pembelajaran peserta didik kurang berpartisipasi, serta banyak peserta didik yang kurang memperhatikan saat guru menjelaskan materi pelajaran. Latihan yang diberikan guru berupa soal-soal rutin yang mengakibatkan peserta didik kurang memahami masalah-masalah matematika untuk meningkatkan kemampuan berpikirnya.

Berdasarkan uji kemampuan pemecahan masalah siswa yang telah dilakukan di SMA Kartika 1-5 Padang dengan menggunakan soal essay, diperoleh data sebagai berikut.

Tabel 1. Hasil Uji Kemampuan Pemecahan Masalah

\begin{tabular}{|l|l|c|}
\hline o & $\begin{array}{c}\text { Aspek } \\
\text { kemampuan } \\
\text { Pemecahan Masalah }\end{array}$ & $\begin{array}{c}\% \\
\text { Kemampuan } \\
\text { Siswa }\end{array}$ \\
\hline & $\begin{array}{l}\text { Memahami } \\
\text { Masalah }\end{array}$ & $36,07 \%$ \\
\hline & $\begin{array}{l}\text { Merencanakan } \\
\text { Penyelesaian }\end{array}$ & $25,47 \%$ \\
\hline & $\begin{array}{l}\text { Menyelesaikan } \\
\text { Masalah }\end{array}$ & $22,56 \%$ \\
\hline & $\begin{array}{c}\text { Memeriksa } \\
\text { Kembali }\end{array}$ & $10,81 \%$ \\
\hline
\end{tabular}

Salah satu solusi untuk mengatasi permasalahan mengenai aktivitas dan partisipasi peserta didik dalam belajar, dapat diwujudkan guru dengan merancang atau menyediakan perangkat pembelajaran seperti Rencana Pelaksanaan Pembelajaran (RPP). Skenario pembelajaran yang dilakasanakan semuanya tergambar dalam RPP baik itu kegitan guru maupun kegitan peserta didik. Pembelajaran yang dilaksanakan untuk mencapai tujuan pembelajaran matematika yaitu berkembangngnya kemampuan berpikir kreatif peserta didik adalah pembelajaran dengan pemecahan masalah. Karena langkahlangkah pembelajran yang akan dilaksanakan tertuang dalan RPP, maka penjabaran langkah-langkah pembelajaran dengan model pembelajran berbasis masalah tersebut digambarkan dalam RPP. Oleh karena itu, RPP akan disusun mengacu pada langkahlangkah pembelajaran dengan pemecahan masalah yaitu model pembelajran berbasis masalah.

Skenario pelaksanaan pembelajaran dengan pendekatan pemecahan masalah akan terimplementasi dengan lebih praktis dan efektif jika dilengkapi dengan LKPD yang memuat serangkaian kegiatan/pertanyaan bagi peserta didik dalam memecahkan suatu masalah matematika. Hal ini juga yang mendasari peneliti memilih pengembangan LKPD karena pada penyusunan LKPD sangat memungkinkan untuk mengarahkan peserta didik untuk memecahkan masalah matematika dalam rangka peningkatan kemampuan pemecahan masalah matematika peserta didik. Kemampuan itu akan membekali peserta didik dalam menghadapi masalah sehari-hari. LKPD yang baik dalam pembelajaran matematika akan memberi kesempatan yang seluas-luasnya kepada peserta didik untuk dapat mengembangkan kreativitas mereka dalam memecahkan suatu masalah.

Berdasarkan uraian di atas, penulis akan melakukan penelitian tentang pengembangan perangkat pembelajaran berupa RPP dan LKPD berbasis pendekatan pemecahan masalah. RPP yang disusun dalam penelitian adalah RPP pada kegiatan inti merujuk pada tahapan-tahapan dalam pembelajaran pendekatan pemecahan masalah. LKPD terdiri dari sekumpulan kegiatan, masalah, atau soal yang akan dikerjakan peserta didik selama proses pembelajaran. LKPD yang berbasis pendekatan pemecahan masalah ini merupakan salah satu sarana yang dapat digunakan guru matematika untuk membantu peserta didik agar dapat meningkatkan kemampuan berpikir kreatif. 


\section{RESEARCH METHODS}

Model pembelajaran berbasis masalah merupakan suatu model pembelajaran yang melatih peserta didik untuk menggunakan kemampuan pemecahan masalah sebagai awal dalam pembelajaran. Sebagaimana yang dinyatakan oleh Hosnan (2014) bahwa model pembelajaran berbasis masalah adalah model pembelajaran dengan pendekatan pembelajaran peserta didik pada masalah autentik sehingga peserta didik dapat menyusun pengetahuannya sendiri, menumbuhkembangkan keterampilan yang lebih tinggi dan inquiry, memandirikan peserta didik dan meningkatkan kepercayaan diri sendiri.

Terdapat berbagai langkah dan tahapan dalam melaksanakan pembelajaran berbasis masalah. Adapun tahapan pembelajaran berbasis masalah menurut Wina dalam Taufik dan Muhammadi (2012) adalah sebagai berikut.

a. Menyadari masalah, dimulai dengan kesadaran adanya masalah yang harus dipecahkan.

b. Merumuskan masalah, topik masalah difokuskan pada masalah apa yang pantas dikaji.

c. Merumuskan hipotesis, dengan menentukan sebab akibat dari masalah yang ingin dijelaskan.

$\begin{array}{ll}\text { d. } & \text { Mengumpulkan data. } \\ \text { e. } & \text { Menguji hipotesis, dengan }\end{array}$ menentukan hipotesis mana yang diterima.

f. Menentukan pilihan penyelesaian.

Rencana pelaksanaan pembelajaran merupakan prosedur yang menggambarkan pengorganisasian pembelajaran untuk mencapai suatu kompetensi dasar yang ditetapkan standar isi yang telah dijabarkan dalam silabus. Menurut Permendikbud No. 65 Tahun 2013, komponen RPP terdiri dari (1) Identitas sekolah, (2) Tema, (3) Kelas, (4) Materi Pokok (5) Alokasi waktu, (6) Kompetensi inti, (7) Kompetensi Dasar, (8) Indikator, (9) Tujuan pembelajaran, (10) Uraian Singkat Materi, (11) Pendekatan dan metode pembelajaran, (12) Kegiatan pembelajaran, (13) Sumber dan media, dan (14) Penilaian.

\section{LKPD Berbasis Pendekatan Pemecahan Masalah}

LKPD yang dimaksud adalah bahan cetak yang berisi masalah, latihan, dan petunjuk-petunjuk pelaksanaan tugas pembelajaran yang harus dikerjakan oleh peserta didik, yang mengacu pada kompetensi dasar yang harus dicapai dengan menggunakan pendekatan pemecahan masalah.

\section{A. Model Pengembangan}

Model pengembangan adalah seperangkat prosedur yang berurutan untuk melaksanakan perancangan dan pengembangan pembelajaran yang diwujudkan dalam bentuk diagram atau naratif. Dalam penelitian ini, model pengembangan yang digunakan diadaptasi dari Model McKenny. Model ini terdiri dari tiga tahap utama, yaitu: (1) preliminary research (analisis pendahuluan), (2) prototyping phase (tahap perancangan), dan (3) assesment stage (Plomp dan Nieveen, 2007: 15).

\section{B. Prosedur Pengembangan}

Tahap pertama adalah Preliminary Research (Analisis Pendahuluan) berisi analisis kurikulum, analisis konsep, analisis karakter siswa. Tahap kedua adalah Prototyping Phase (tahap perancangan) yang terdiri dari beberapa tahapan yaitu Prototype 1, Prototype 2, Prototype 3, Prototype 4. Selain untuk melihat kepraktisan suatu produk, pada tahap prototype 4 ini, juga dilihat keefektivan perangkat yang dikenal dengan tahap assesment stage.

Uji efektivitas digunakan untuk mengetahui tingkat penerapan teori atau model yang digunakan dalam suatu kondisi tertentu. Pada penelitian ini, efektivitas perangkat pembelajaran berbasis pemecahan masalah dapat diketahui dari aktivitas siswa selama pembelajaran dan hasil belajar siswa setelah pembelajaran. Pada tahap ini dilakukan evaluasi untuk mengetahui apakah perangkat yang dirancang efektif untuk meningkatkan hasil belajar dan memicu berpikir kreatif peserta didik.

Jurnal JIPS (Jurnal Ilmiah Pendidikan Scholastic) Vol. 4 No. 3 (2020) ISSN : 2579-5449

This work is licensed under a Creative Commons Attribution-NonCommercial 4.0 International License. 


\section{RESULTS AND DISCUSSION}

Uji validitas perangkat pembelajaran berbasis pendekatan pemecahan masalah dilakukan oleh 3 orang dosen Pendidikan Matematika, 2 orang dosen Pendidikan Bahasa Indonesia. Berikut diuraikan hasil validasi RPP dan LKPD.

a. Hasil validasi RPP

Validasi RPP dilakukan oleh 5 orang pakar, yaitu 3 orang dosen matematika, 2 orang dosen Bahasa Indonesia. Selama tahap validasi RPP terdapat beberapa revisi yang dilakukan berdasarkan saran-saran dari validator. Saran validator untuk RPP dapat dilihat pada Tabel 6 .

Tabel 6. Saran Validator dan Revisi RPP

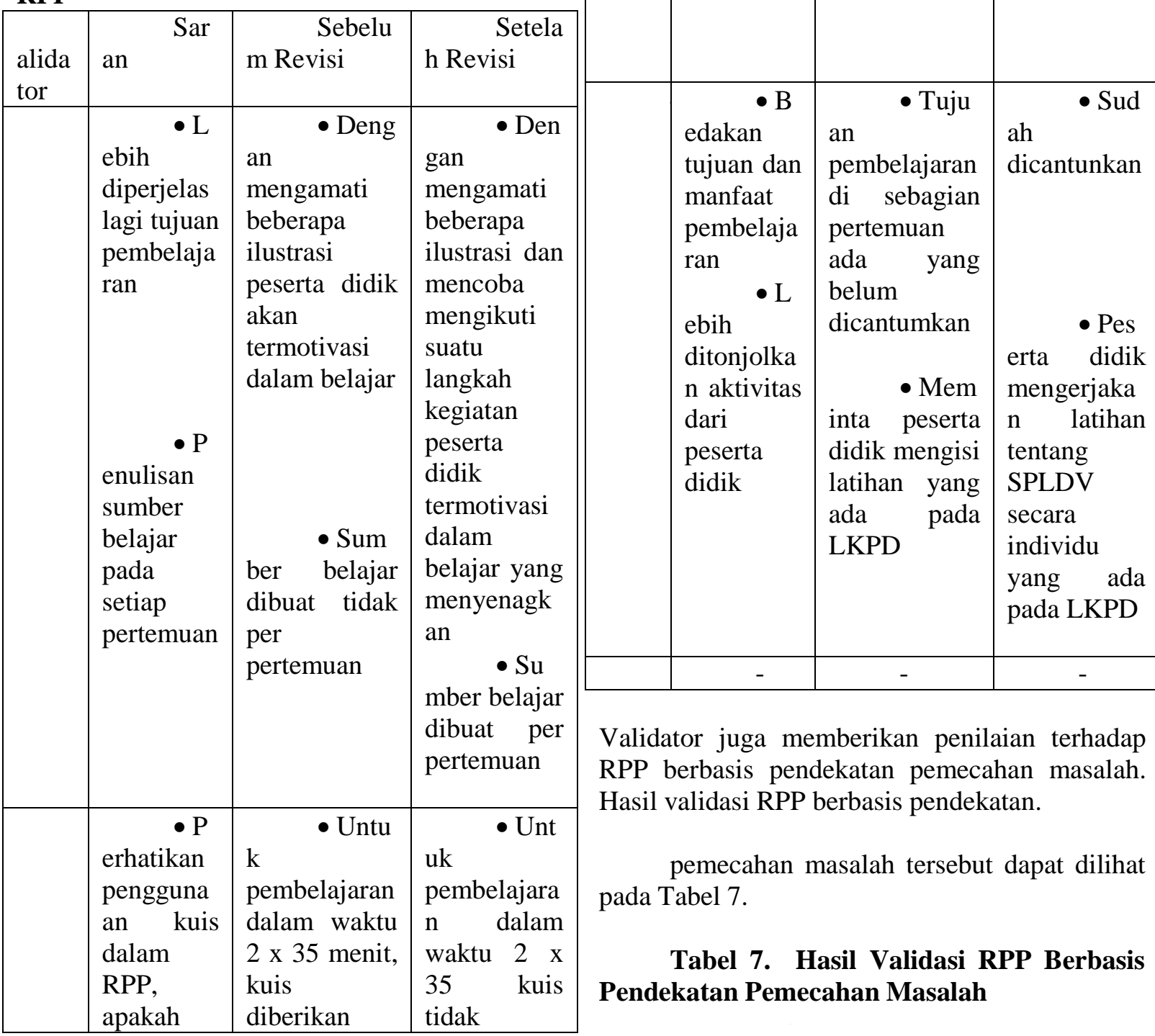

Jurnal JIPS (Jurnal Ilmiah Pendidikan Scholastic ) Vol. 4 No. 3 (2020) ISSN : 2579-5449

This work is licensed under a Creative Commons Attribution-NonCommercial 4.0 International License. 


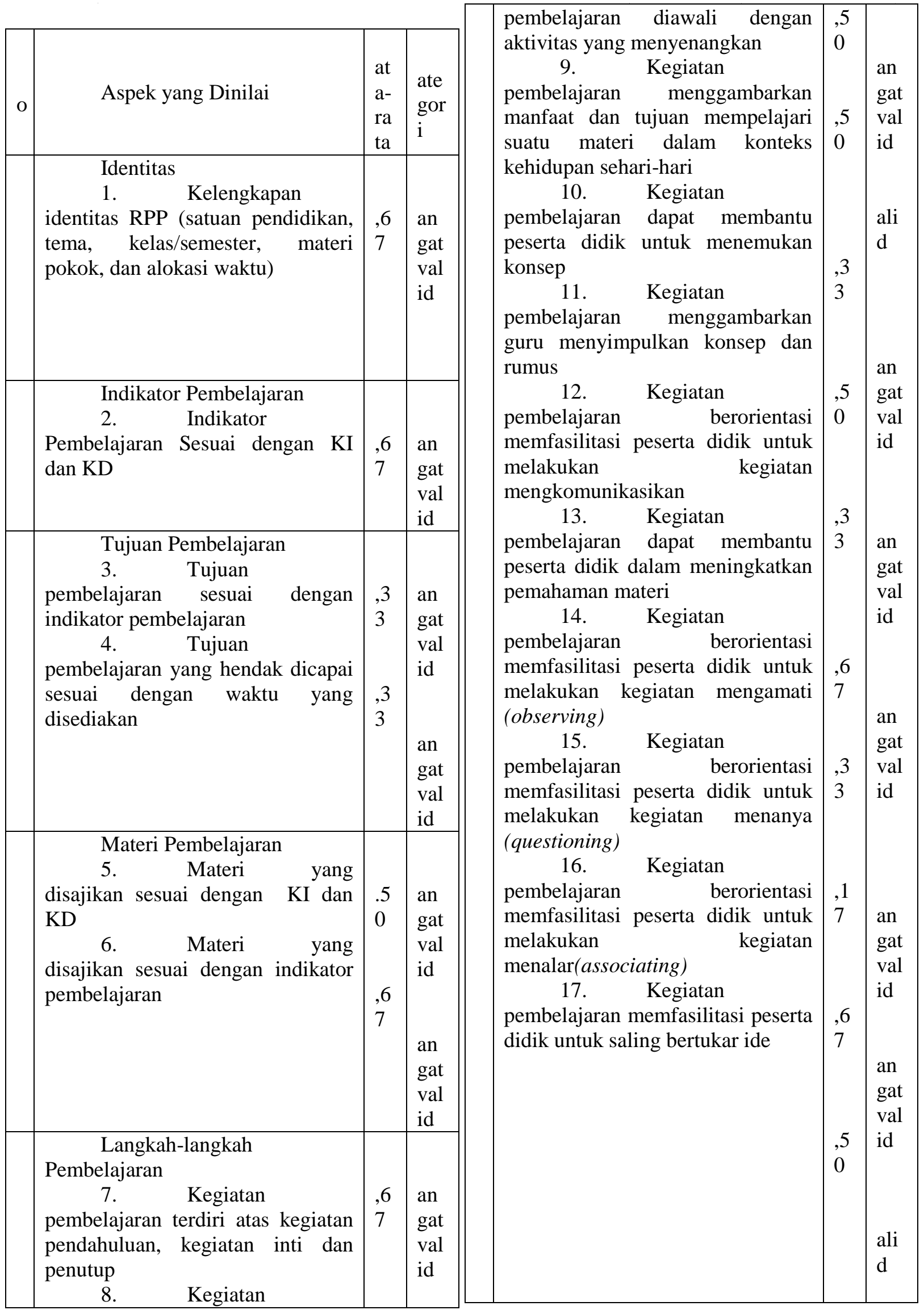

Jurnal JIPS (Jurnal Ilmiah Pendidikan Scholastic ) Vol. 4 No. 3 (2020) ISSN : 2579-5449

This work is licensed under a Creative Commons Attribution-NonCommercial 4.0 International License. 


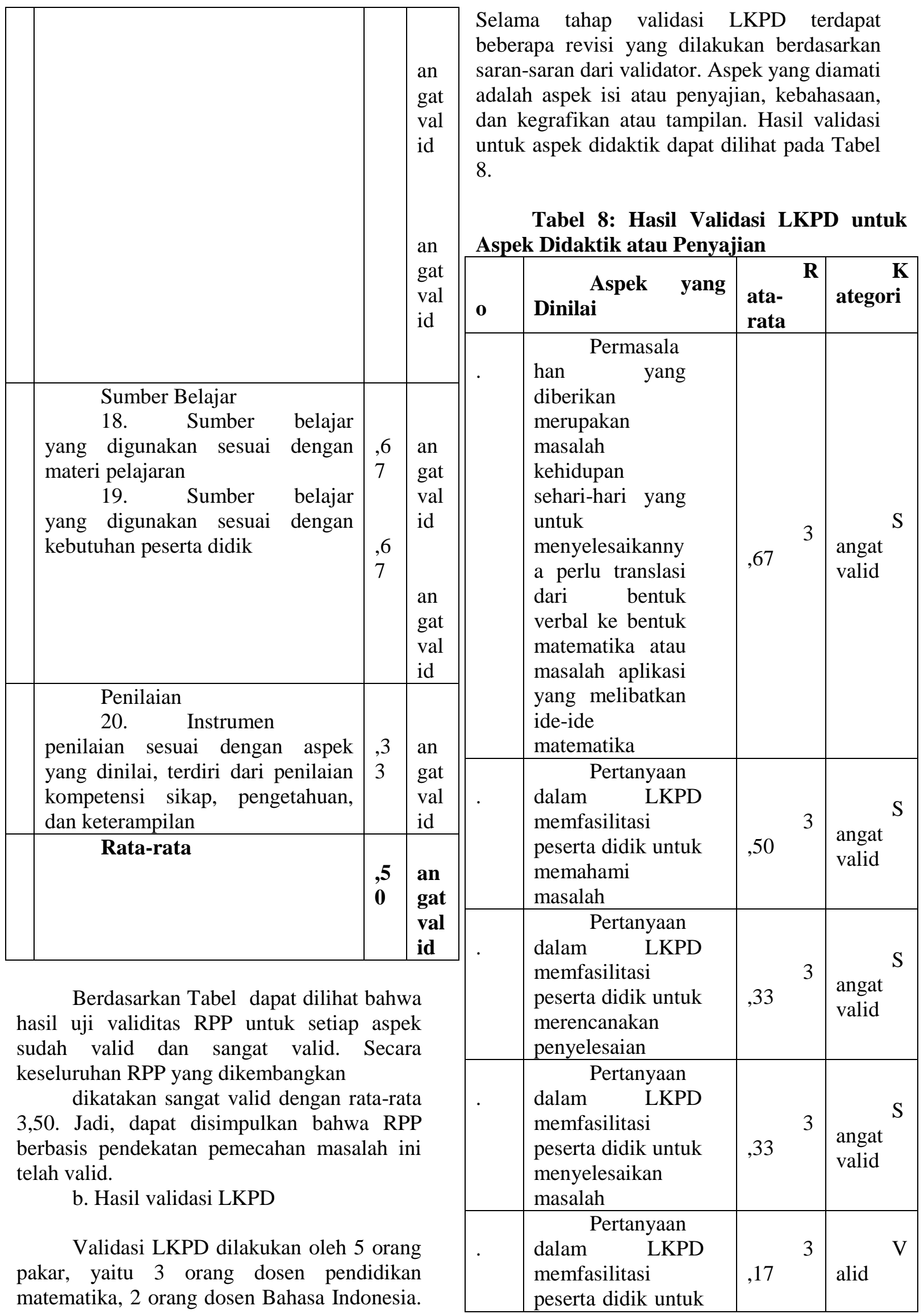

Jurnal JIPS (Jurnal Ilmiah Pendidikan Scholastic ) Vol. 4 No. 3 (2020) ISSN : 2579-5449

This work is licensed under a Creative Commons Attribution-NonCommercial 4.0 International License. 


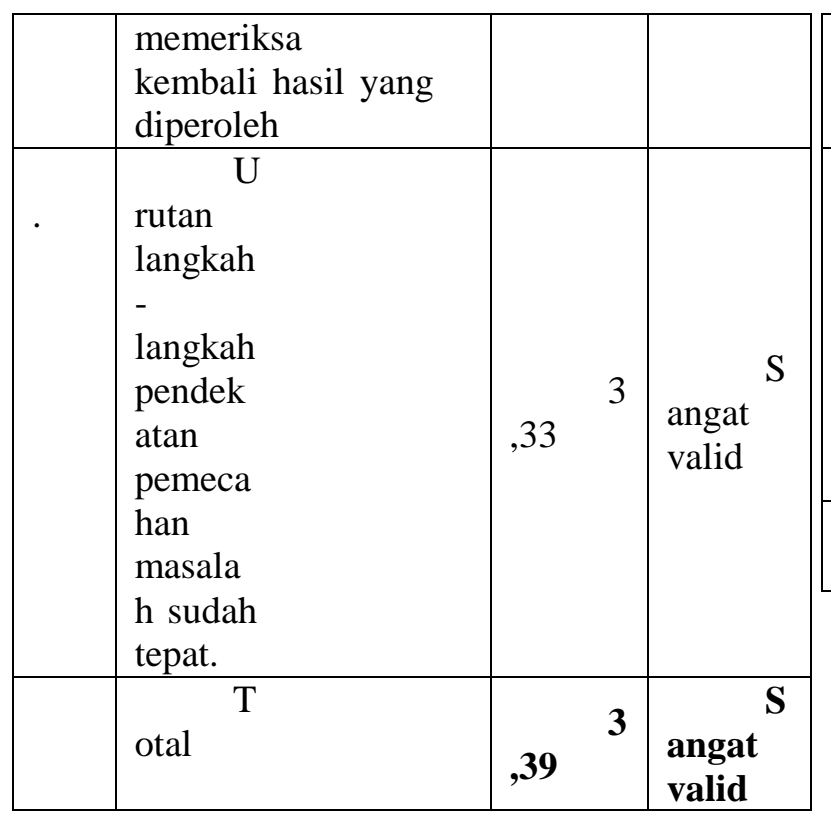

\begin{tabular}{|c|c|c|}
\hline $\begin{array}{l}\text { membantu } \\
\text { pemahaman } \\
\text { peserta didik }\end{array}$ & & \\
\hline \begin{tabular}{lr}
\multicolumn{2}{c}{ LKPD } \\
dilengkapi \\
dengan & contoh \\
dan latihan & soal \\
yang & sesuai \\
dengan & tingkat \\
kognisi & peserta \\
didik &
\end{tabular} & ,00 & Vali \\
\hline Rata-rata & $\begin{array}{ll} & 3 \\
, 42 & \end{array}$ & $\begin{array}{l}\text { Sang } \\
\text { at valid }\end{array}$ \\
\hline
\end{tabular}

Berdasarkan Tabel 9 terlihat bahwa nilai rata-rata setiap indikator pada aspek materi berkisar dari 3,00 hingga 4,00 dengan kategori valid dan sangat valid. Secara umum validitas LKPD dari aspek didaktik dan materi adalah 3,42

Berdasarkan Tabel 8 terlihat bahwa nilai rata-rata setiap indikator pada aspek didaktik berkisar dari 3,39 hingga 4,00 dengan kategori sangat valid.

Secara umum validitas LKPD dari aspek didaktik adalah 3,39 dengan kategori sangat valid. Hasil validasi menggambarkan masalah yang disajikan dalam LKPD terkait dengan tujuan pembelajaran dan menampilkan gambargambar yang dapat membantu pemahaman peserta didik. Aspek selanjutnya yang dilihat adalah aspek materi atau isi. Berikut merupakan hasil validasi LKPD untuk aspek isi.

Tabel 9. Hasil Validasi LKPD untuk Aspek Isi

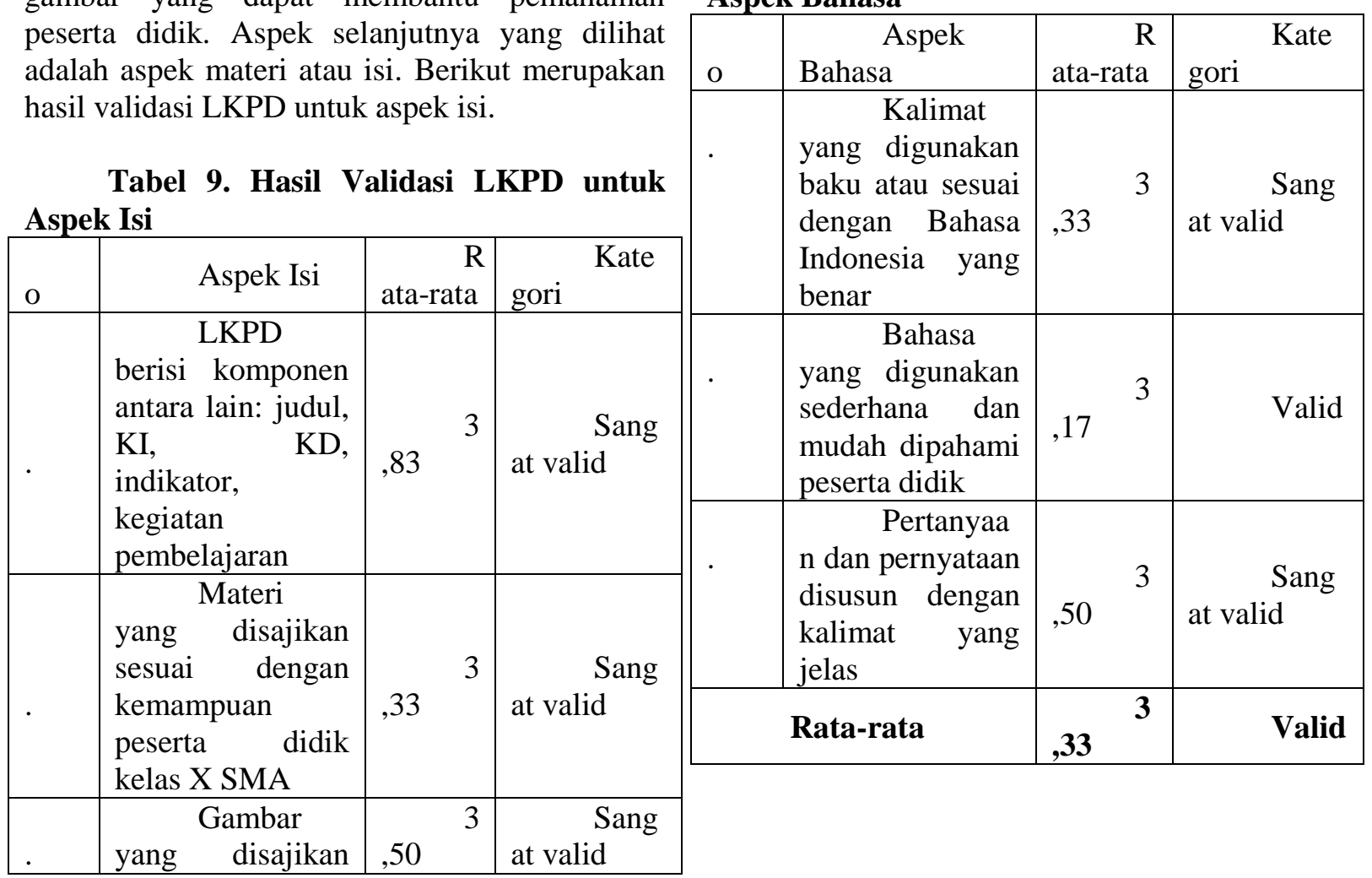

Tabel 10. Hasil Validasi LKPD untuk Aspek Bahasa menggambarkan materi yang disajikan dalam LKPD sudah valid. Selanjutnya, Aspek bahasa juga diamati dalam penilaian LKPD berbasis pendekatan pemecahan masalah. Hasil validasi LKPD berbasis pendekatan pemecahan masalah dapat dilihat pada tabel 10 berikut.

Jurnal JIPS (Jurnal Ilmiah Pendidikan Scholastic ) Vol. 4 No. 3 (2020) ISSN : 2579-5449

This work is licensed under a Creative Commons Attribution-NonCommercial 4.0 International License. 
Berdasarkan Tabel 10 terlihat bahwa ratarata validitas LKPD dari aspek bahasa adalah 3,17 dengan kategori sangat valid. Aspek terakhir yang divalidasi adalah aspek kegrafikan atau tampilan. Aspek terakhir yang divalidasi adalah aspek penyajian. Berikut merupakan hasil validasi LKPD dari aspek penyajian.

Tabel 11 . Hasil Validasi LKPD untuk Aspek Penyajian

\begin{tabular}{|c|c|c|c|}
\hline $\mathrm{N}$ & $\begin{array}{l}\text { Aspek } \\
\text { Penyajian }\end{array}$ & $\begin{array}{l}\text { ata- } \\
\text { rata }\end{array}$ & egori ${ }^{\text {Kat }}$ \\
\hline 1 & \begin{tabular}{l}
\multicolumn{1}{c}{ Gambar } \\
yang disajikan \\
berfungsi \\
mengaitkan \\
materi dengan \\
kehidupan nyata
\end{tabular} &, 50 & \begin{tabular}{|l} 
San \\
gat valid
\end{tabular} \\
\hline 2 & \begin{tabular}{l}
\multicolumn{1}{c}{ Desain } \\
cover sederhana \\
dan menarik
\end{tabular} &, 50 & \begin{tabular}{|l} 
San \\
gat valid
\end{tabular} \\
\hline 3 & \begin{tabular}{l}
\multicolumn{1}{c}{ LKPD } \\
menggunakan \\
huruf berbagai \\
tipe yang mudah \\
dibaca peserta \\
didik
\end{tabular} & ,33 & \begin{tabular}{|l} 
San \\
gat valid
\end{tabular} \\
\hline 4 & \begin{tabular}{lr}
\multicolumn{2}{c}{ Bagian } \\
judul dan bagian \\
yang perlu \\
mendapat \\
penekanan \\
dicetak tebal \\
atau diberikan \\
warna yang \\
berbeda
\end{tabular} & ,33 & \begin{tabular}{|c} 
San \\
gat valid
\end{tabular} \\
\hline \multicolumn{2}{|c|}{ Rata-rata } &, $415^{3}$ & \begin{tabular}{|r|} 
San \\
gat valid
\end{tabular} \\
\hline
\end{tabular}

Berdasarkan Tabel 11 terlihat bahwa nilai rata-rata setiap indikator aspek penyajian berkisar mulai dari 3 hingga 3,5 aspek kegrafikan berkisar dari 3,00 hingga 4,00 dengan kategori valid dan sangat valid. Secara umum validitas LKPD dari kegrafikan adalah 3,415 dengan kategori sangat valid. Jadi dapat disimpulkan bahwa LKPD berbasis pendekatan pemecahan masalah sudah valid. Secara keseluruhan validitas dari LKPD dapat dilihat pada Tabel di bawah ini..

Tabel 12. Hasil Validasi LKPD secara Keseluruhan

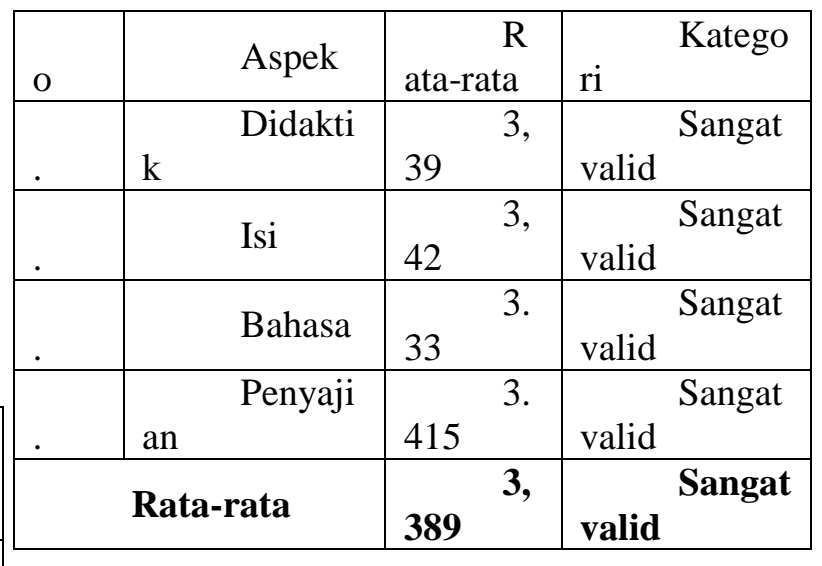

Berdasarkan Tabel 12 terlihat bahwa ratarata validasi LKPD secara keseluruhan adalah 3,389 dengan kategori sangat valid.

. Jadi, dapat disimpulkan bahwa LKPD berbasis pendekatan pemecahan masalah telah valid. Setelah proses validasi selesai, dilakukan perbaikan terhadap prototype I sesuai dengan saran validator. Hasil revisi pada prototype I ini dinamakan dengan prototype II.

\section{a. Praktikalitas Perangkat} Pembelajaran Berbasis Pendekatan Pemecahan Masalah

Selanjutnya, dilakukan uji praktikalitas LKPD berbasis pendekatan

pemecahan masalah yang telah diperbaiki di prototype II. Uji praktikalitas bertujuan untuk mengetahui sejauh mana manfaat, kemudahan penggunaan dan efesiensi waktu penggunaan LKPD berbasis pendekatan pemecahan masalah oleh guru dan peserta didik. Hasil praktikalitas LKPD dideskripsikan sebagai berikut.

b. Hasil Evaluasi Perorangan (One To One Evaluation)

Evaluasi perorangan ini dilakukan dengan meminta 4 orang peserta didik untuk mencoba mengisi LKPD. Ketiganya berasal dari kelas X SMA Kartika 1-5

Padang yang memiliki kemampuan berbeda yaitu dua orang berkemampuan sedang dan dua orang berkemampuan rendah. Peserta didik yang berkemampuan rendah adalah SAU dan AZI, sedangkan yang berkemampuan sedang adalah WSN dan

Jurnal JIPS (Jurnal Ilmiah Pendidikan Scholastic ) Vol. 4 No. 3 (2020) ISSN : 2579-5449

This work is licensed under a Creative Commons Attribution-NonCommercial 4.0 International License. 
MGA. Mereka diminta untuk mencoba mengisi LKPD sesuai kemampuan mereka masing-masing dan setelah itu diminta untuk memberikan komentar terhadap LKPD yang diberikan.

Berdasarkan pengamatan tersebut dapat disimpulkan bahwa kendala yang didapatkan pada pengerjaan LKPD ini adalah narasi cerita pada masalah terlalu panjang, ketidakpahaman peserta didik mengenai instruksi "Berdasarkan informasi yang diketahui dari masalah, apa yang dapat Ananda jelaskan?", dan kurang tepatnya menuliskan informasi yang diketahui dari masalah.

Berdasarkan rincian pelaksanaan evaluasi perorangan ini, secara umum revisi hanya sebatas pada kalimat saja. Peneliti melakukan perbaikan perangkat pembelajaran berbasis pendekatan pemecahan masalah untuk mendapatkan perangkat pembelajaran yang lebih baik lagi. Hasil perbaikan perangkat pembelajaran berbasis pendekatan pemecahan masalah ini dinamakan prototype III.

c. Hasil Evaluasi Kelompok Kecil (Small Group Evaluation)

Selain melakukan evaluasi perorangan, dilakukan evaluasi kelompok kecil dengan mempraktekkan perangkat pembelajaran yang telah dirancang pada peserta didik kelas $\mathrm{X}$ SMA Kartika 1-5 Padang yang berjumlah 8 orang yang berasal dari kemampuan tinggi, sedang dan rendah dan dibagi menjadi dua kelompok dengan kemampuan yang heterogen. Evaluasi kelompok kecil dilakukan selama 3 kali pertemuan pada merancang model matematika dari masalah yang berkaitan dengan SPLDV dan menyelesaikan model matematika dari masalah yang berkaitan dengan SPLDV.

Berdasarkan evaluasi kelompok kecil (small group evaluation) LKPD berbasis pendekatan pemecahan masalah dapat membantu peserta didik dalam memahami materi yang dipelajari. Ada terdapat beberapa revisi dari perangkat pembelajaran yaitu pada kegiatan mempresentasikan hasil diskusi dan mengerjakan latihan pada LKPD. Hasil pengamatan, peneliti hanya melakukan revisi dari segi waktu, peserta didik membutuhkan waktu yang cukup lama dalam mengerjakan latihan yang terdapat pada LKPD berbasis pendekatan pemecahan masalah, sehingga peneliti melakukan revisi pada alokasi waktu pengerjaan latihan yang terdapat pada RPP dari 10 menit menjadi 15 menit. Namun setelah diwawancarai, secara umum mereka bisa mengerjakan LKPD ini dengan baik.

Berdasarkan evaluasi kelompok kecil, dilakukan revisi terhadap perangkat pembelajaran khususnya LKPD. Hasil revisi dinamakan prototype IV.

\section{Tahap Penilaian (Assesment Phase)}

$\begin{array}{lrr}\text { 1. } & \text { Praktikalitas } & \begin{array}{r}\text { Perangkat } \\ \text { Pendekatan } \\ \text { pemelajaran }\end{array} \\ \text { Berbasis } & \text { Penan }\end{array}$

\section{masalah}

Setelah dilakukan revisi berdasarkan hasil evaluasi perorangan dan evaluasi kelompok kecil, selanjutnya perangkat pembelajaran diujicobakan praktikalitasnya di kelas $\mathrm{X}_{5}$ SMA Kartika 1-5 Padang. Uji coba perangkat pembelajaran berbasis pendekatan pemecahan masalah dilakukan sebanyak 6 kali pertemuan. Data uji coba perangkat pembelajaran berbasis pendekatan pemecahan masalah diperoleh dari angket respon guru, angket respon peserta didik dan observasi pelaksanaan pembelajaran.

a. Hasil Angket Praktikalitas Menurut Respon Guru

Angket praktikalitas diberikan kepada guru setelah pembelajaran dilaksanakan. Angket ini digunakan untuk mendapatkan penilaian atau respon guru terhadap perangkat pembelajaran berbasis pendekatan pemecahan masalah. Angket kepraktisan yang diukur meliputi kemudahan guru dalam menggunakan LKPD, efisiensi waktu, daya tarik, kemudahan dipahami dan ekuvalensi LKPD.

Hasil penilaian terhadap angket dapat dilihat pada Tabel 13. 


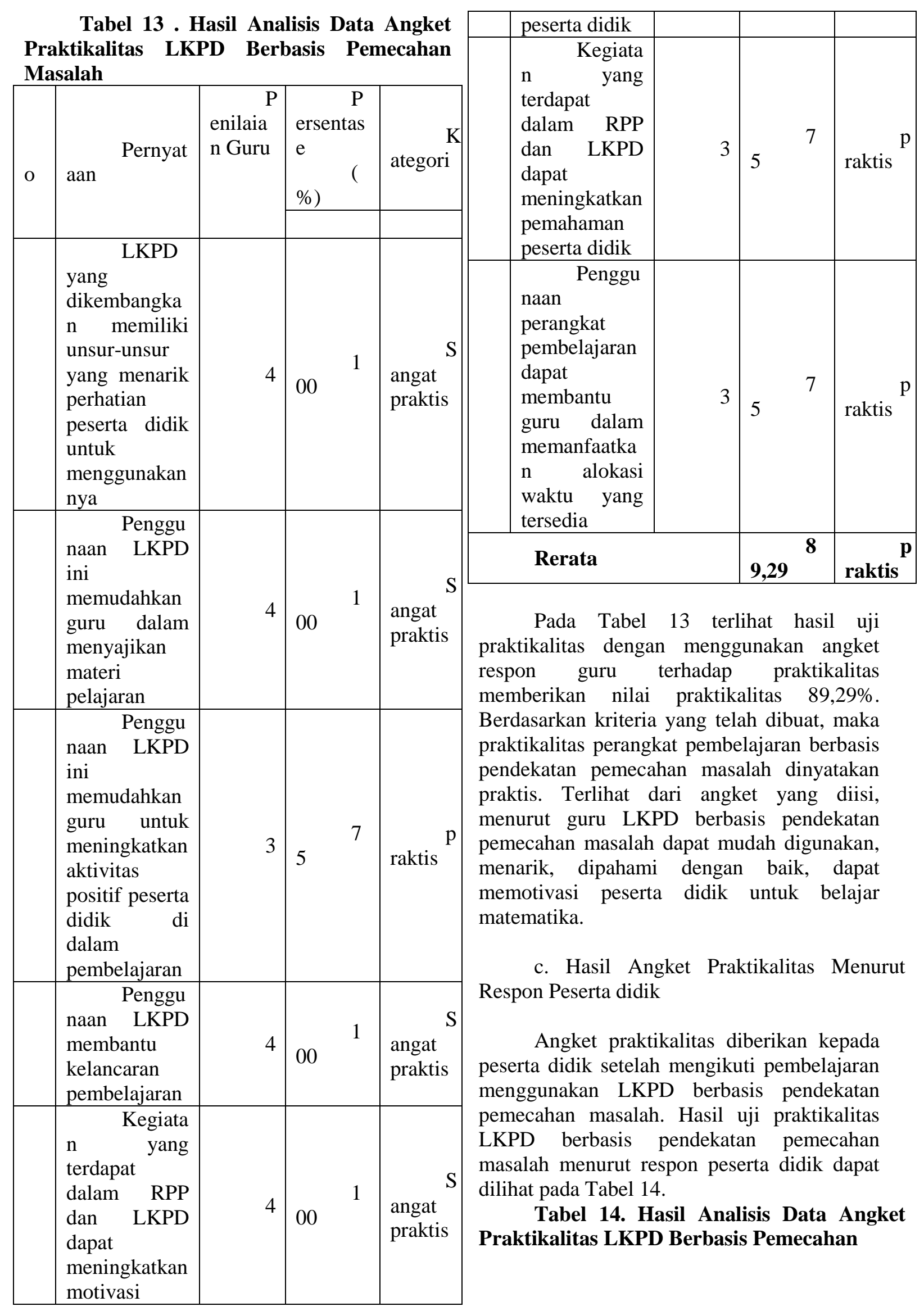

Jurnal JIPS (Jurnal Ilmiah Pendidikan Scholastic ) Vol. 4 No. 3 (2020) ISSN : 2579-5449

This work is licensed under a Creative Commons Attribution-NonCommercial 4.0 International License. 


\begin{tabular}{|l|l|l|l|}
\hline Pernyataan & $\begin{array}{l}\text { Perse } \\
\text { ntase } \\
\text { Kepraktisan } \\
(\%)\end{array}$ & $\begin{array}{r}\text { K } \\
\text { ategori }\end{array}$ \\
\hline $\begin{array}{l}\text { LKPD yang } \\
\text { dibuat memiliki } \\
\text { tampilan yang } \\
\text { menarik }\end{array}$ & 96,7 & $\begin{array}{l}\text { angat } \\
\text { praktis }\end{array}$ \\
\hline $\begin{array}{l}\text { Kata-kata } \\
\text { dan kalimat di } \\
\text { dalam LKPD } \\
\text { mudah dibaca dan } \\
\text { dipahami Penggunaan }\end{array}$ & 93,48 & $\begin{array}{l}\text { angat } \\
\text { praktis }\end{array}$ \\
\hline $\begin{array}{l}\text { LKPD membantu } \\
\text { proses pelaksanaan } \\
\text { pembelajaran }\end{array}$ & 92,3 & $\begin{array}{l}\text { angat } \\
\text { praktis }\end{array}$ \\
\hline $\begin{array}{l}\text { Saya dapat } \\
\text { belajar secara } \\
\text { mandiri dengan } \\
\text { menggunakan } \\
\text { LKPD ini }\end{array}$ & 89,1 & $\begin{array}{l}\text { angat } \\
\text { praktis }\end{array}$ \\
\hline
\end{tabular}

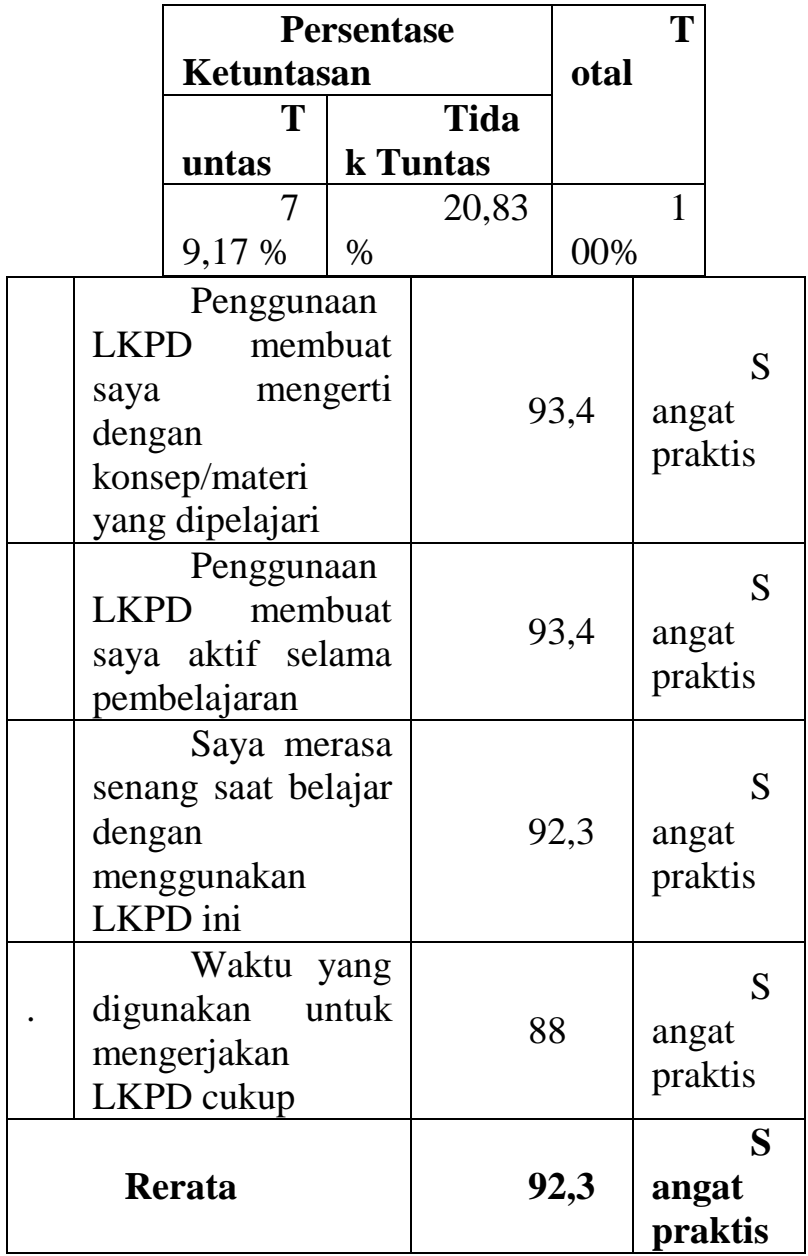

Berdasarkan Tabel 14, terlihat bahwa ratarata hasil uji praktikalitas oleh peserta didik kelas X SMA Kartika 1-5 Padang berbasis pemecahan masalah berada pada rentang $88 \%$ s/d $97 \%$ dengan kriteria sangat praktis. Rata-rata kepraktisan LKPD adalah 92,3\% dengan kriteria sangat praktis. Dengan demikian dapat disimpulkan bahwa siswa memandang LKPD berbasis pemecahan masalah ini praktis untuk digunakan pada pembelajaran matematika kelas X SMA.

\section{Efektivitas}

\section{Pembelajaran Berbasis Pendekatan} Pemecahan Masalah

Efektivitas perangkat pembelajaran matematika dilihat dari hasil tes kemampuan pemecahan masalah matematika peserta didik setelah pembelajaran dengan menggunakan perangkat pembelajaran matematika berbasis pendekatan pemecahan masalah. Perangkat pembelajaran berbasis pendekatan pemecahan masalah dapat dikatakan efektif apabila mampu meningkatkan kemampuan pemecahan masalah matematika peserta didik. Soal tes yang diberikan sebanyak 3 buah soal. Soal tes divalidasi kepada 2 orang dosen pendidikan matematika.

\section{Tabel 15. Persentase Ketuntasan}

Berdasarkan Tabel 15 di atas terlihat bahwa dari 24 orang peserta didik yang mengikuti tes, 19 orang peserta didik atau sebesar 79,17\% tuntas artinya nilai peserta didik diatas nilai KKM yang ditentukan dan 5 orang peserta didik atau sebesar 20,83\% belum tuntas artinya nilai peserta didik masih dibawah KKM. Peneliti juga menganalisis persentase jawaban peserta didik untuk setiap indikator kemampuan pemecahan masalah. Hasil analisisnya dapat dilihat pada Tabel 16.

Jurnal JIPS (Jurnal Ilmiah Pendidikan Scholastic ) Vol. 4 No. 3 (2020) ISSN : 2579-5449 
Tabel 16. Hasil Analisis Kemampuan pemecahan Masalah untuk Setiap Indikator

\begin{tabular}{|c|c|c|c|c|c|c|}
\hline $\begin{array}{l}\mathrm{O} \\
\mathrm{a} \\
\mathrm{l}\end{array}$ & $\begin{array}{l}\text { oal } \\
\text { ndikat } \\
\text { or }\end{array}$ & & & & & \\
\hline & $\begin{array}{l}\text { M } \\
\text { emaha } \\
\text { mi } \\
\text { Masal } \\
\text { ah }\end{array}$ & & $\begin{array}{l}2,0 \\
5 \%\end{array}$ & $\begin{array}{l}7,9 \\
5 \%\end{array}$ & & \\
\hline & $\begin{array}{l}\quad \text { M } \\
\text { erenca } \\
\text { nakan } \\
\text { Penyel } \\
\text { esaian }\end{array}$ & $\begin{array}{l}70 \\
\%\end{array}$ & $\begin{array}{l}6,7 \\
2 \%\end{array}$ & $\begin{array}{l}4,5 \\
8 \%\end{array}$ & & \\
\hline & $\begin{array}{l}\text { M } \\
\text { enyele } \\
\text { saikan } \\
\text { Masal } \\
\text { ah }\end{array}$ & & & $\begin{array}{l}45 \\
\%\end{array}$ & & $\begin{array}{l}5,5 \\
5 \%\end{array}$ \\
\hline & $\begin{array}{l}\quad \text { M } \\
\text { emeri } \\
\text { ksa } \\
\text { Kemb } \\
\text { ali }\end{array}$ & $\begin{array}{l}, 35 \\
\%\end{array}$ & $\begin{array}{l}, 35 \\
\%\end{array}$ & $\begin{array}{l}0,3 \\
0 \%\end{array}$ & $\begin{array}{l}, 35 \\
\%\end{array}$ & $\begin{array}{l}, 35 \\
\%\end{array}$ \\
\hline & $\begin{array}{l}\quad M \\
\text { emaha } \\
\text { mi } \\
\text { Masal } \\
\text { ah }\end{array}$ & & $\begin{array}{l}, 70 \\
\%\end{array}$ & $\begin{array}{l}2,3 \\
0 \% \\
\end{array}$ & & \\
\hline & $\begin{array}{l}\quad \text { M } \\
\text { erenca } \\
\text { nakan } \\
\text { Penyel } \\
\text { esaian }\end{array}$ & $\begin{array}{l}, 35 \\
\%\end{array}$ & $\begin{array}{l}1,2 \\
9 \%\end{array}$ & $\begin{array}{l}3,4 \\
6 \%\end{array}$ & & \\
\hline & $\begin{array}{l}\text { M } \\
\text { enyele } \\
\text { saikan } \\
\text { Masal }\end{array}$ & & $\begin{array}{l}, 35 \\
\%\end{array}$ & $\begin{array}{l}2,0 \\
4 \%\end{array}$ & $\begin{array}{l}3,0 \\
4 \%\end{array}$ & $\begin{array}{l}9,5 \\
7 \%\end{array}$ \\
\hline
\end{tabular}

\begin{tabular}{|c|c|c|c|c|c|}
\hline ah & & & & & \\
\hline \begin{tabular}{l}
\multicolumn{1}{c}{ M } \\
emeri \\
ksa \\
Kemb \\
ali \\
\end{tabular} & $\begin{array}{l}3,0 \\
4 \% \\
\end{array}$ & $\begin{array}{l}3,0 \\
4 \% \\
\end{array}$ & $\begin{array}{l}3,9 \\
2 \% \\
\end{array}$ & & \\
\hline \begin{tabular}{l}
\multicolumn{1}{c}{ M } \\
emaha \\
mi \\
Masal \\
ah
\end{tabular} & $\begin{array}{l}, 75 \\
\%\end{array}$ & $\begin{array}{l}3,7 \\
3 \% \\
\end{array}$ & $\begin{array}{l}7,5 \\
2 \%\end{array}$ & & \\
\hline $\begin{array}{l}\quad \mathrm{M} \\
\text { erenca } \\
\text { nakan } \\
\text { Penyel } \\
\text { esaian }\end{array}$ & $\begin{array}{l}0,1 \\
3 \% \\
\end{array}$ & $\begin{array}{l}5,8 \\
3 \% \\
\end{array}$ & $\begin{array}{l}4,0 \\
4 \% \\
\end{array}$ & & \\
\hline $\begin{array}{l}\text { M } \\
\text { enyele } \\
\text { saikan } \\
\text { Masal } \\
\text { ah }\end{array}$ & $\begin{array}{l}3,0 \\
4 \% \\
\end{array}$ & & $\begin{array}{l}70 \\
\%\end{array}$ & $\begin{array}{l}70 \\
\%\end{array}$ & $\begin{array}{l}9,5 \\
7 \%\end{array}$ \\
\hline $\begin{array}{l}\text { M } \\
\text { emeri } \\
\text { ksa } \\
\text { Kemb } \\
\text { ali }\end{array}$ & $\begin{array}{l}9,3 \\
9 \%\end{array}$ & $\begin{array}{l}4,1 \\
0 \%\end{array}$ & $\begin{array}{l}6,5 \\
1 \%\end{array}$ & & \\
\hline
\end{tabular}

Berdasarkan Tabel 16 terlihat bahwa adanya peningkatan persentase pencapaian peserta didik pada pencapaian peserta didik pada skor ideal pada masing-masing indikator. Hasil analisis tes kemampuan pemecahan masalah matematis yang telah diperoleh, maka dapat disimpulkan bahwa perangkat pembelajaran berbasis pendekatan pemecahan masalah telah dapat dinyatakan efektif atau dapat meningkatkan kemampuan pemecahan masalah peserta didik.

Jurnal JIPS (Jurnal Ilmiah Pendidikan Scholastic) Vol. 4 No. 3 (2020) ISSN : 2579-5449 


\section{CONCLUSION}

Penelitian ini merupakan penelitian pengembangan yang menghasilkan perangkat pembelajaran berbasis pendekatan pemecahan masalah berupa RPP dan LKPD. Berdasarkan penelitian yang telah dilaksanakan, maka diperoleh kesimpulan

a. Perangkat pembelajaran berbasis pendekatan pemecahan masalah yang dikembangkan sudah valid baik dari segi isi maupun konstruk.

$$
\text { b. Perangkat pembelajaran }
$$

matematika berbasis pendekatan pemecahan masalah yang dikembangkan sudah memenuhi kriteria praktis baik dari aspek keterlaksanaan, kemudahan dan waktu yang diperlukan. Hal ini dapat dilihat dari data empiris, yaitu data angket praktikalitas menurut peserta didik, angket respon guru dan data hasil observasi pelaksanaan pembelajaran. Perangkat pembelajaran matematika berbasis pendekatan pemecahan masalah yang dikembangkan sudah efektif, dilihat dari data empiris. a. Perangkat pembelajaran berbasis pendekatan pemecahan masalah untuk materi sistem persamaan linear dan pertidaksamaan satu variabel pada sekolah menengah atas (SMA) yang dikembangkan ini telah dinyatakan valid, praktis dan efektif, sehingga disarankan untuk dapat digunakan oleh guru matematika sebagai alternatif perangkat pembelajaran dalam pembelajaran sistem persamaan linear dan pertidaksamaan satu variabel kelas X SMA.

b. Diharapkan ada ujicoba lanjutan di sekolah lain untuk melihat praktikalitas dan efektivitas yang lebih luas terhadap perangkat pembelajaran yang dikembangkan tersebut.

Bagi peneliti lain yang akan melanjutkan penelitian ini, disarankan untuk melakukan inovasi dalam penelitian berikutnya seperti pengembangan perangkat pembelajaran matematika untuk materi lain atau inovasi perangkat pembelajaran matematika yang baru. 


\section{Bibliography}

[1]Arikunto, S. 2005. Dasar-Dasar Evaluasi Pendidikan. Jakarta: Bumi Aksara.

[2]Evans, JR. 1994. Berpikir Kreatif: Dalam Pengambilan Keputusan dan Manajemen. Jakarta: Bumi Aksara.

[3]Hosnan, M. 2014. Pendekatan Saintifik dan Kontekstual dalam pembelajaran Abad 21: Kunci Sukses Implementasi Kurikulum 2013. Bogor: Ghalia Indonesia.

[4]Muliyardi. 2002. Strategi Pembelajaran Matematika. Padang: Jurusan Matematika FMIPA Universitas Negeri Padang
[5]Munandar, U. 1999. Mengembangkan Bakat dan Kreativitas Anak Sekolah. Jakarta: PT. Gramedia Widiasarana Indonesia.

[6]Rusman. 2012. Model-Model Pembelajaran: Mengembangkan Profesionalisme Guru. Depok: PT. Rajagrafindo Persada.

[7]Sudjana, Nana. 2005. Penilaian Hasil Proses Belajar Mengajar. Bandung: Remaja Rosdakarya

[8]Sudijono, Anas. 2005. Pengantar Statistika Pendidikan. Jakarta:Raja Grafindo Persada

[9]Taufik, T. dan Muhammadi. 2012. Mozaik Pembelajaran Inovatif. Padang: Sukabina Press. 